\title{
PERANCANGAN BOARD GAME \\ SEBAGAI MEDIA PEMBELAJARAN PANCASILA UNTUK KELAS 3 SD MENGGUNAKAN MEKANIK CO-OPERATIVE PLAY
}

\author{
Kelvin Adriel Setiawan ${ }^{1}$, T. Arie Setiawan Prasida ${ }^{2}$, Jasson Prestiliano ${ }^{3}$ \\ 1,2,3 Fakultas Teknologi Informasi, Universitas Kristen Satya Wacana \\ 692013012@student.uksw.edu¹, arie.setiawan.p@gmail.com², jasprelao@gmail.com³
}

\begin{abstract}
Abstrak
Pancasila adalah ideologi masyarakat Indonesia. Pancasila digunakan sebagai pedoman untuk membangun karakter bangsa. Namun pada kenyataannya, nilai Pancasila di masyarakat terutama di kalangan anak-anak mulai memudar terlihat pada perilaku anak-anak yang seperti tidak memiliki moral. Salah satu penyebab pudarnya nilai-nilai Pancasila adalah pendidikan di Indonesia yang kurang menanamkan nilai Pancasila di dalam kelas dan metode pembelajaran yang membosankan sehingga membuat siswa kurang bersemangat ketika mempelajari Pendidikan Kewarganegaraan. Penelitian ini menghasilkan board game yang dirancang menggunakan metode perancangan studio game Kummara sebagai media pembelajaran inovatif. Selain itu, penelitian ini juga bertujuan untuk menarik minat belajar siswa dan menanamkan nilai karakter secara tidak langsung lewat aturan dalam permainan dan secara langsung lewat bimbingan yang diberikan saat permainan. Respon baik diberikan oleh muridmurid, dimana murid-murid merasa senang belajar Pancasila dengan board game ini dan adanya peningkatan nilai dari hasil tes yang diberikan kepada murid-murid.
\end{abstract}

Kata Kunci: pancasila, board game, pendidikan, sekolah dasar

\begin{abstract}
Pancasila is the ideology of the Indonesian people. Pancasila be used as a guideline to build national character. But in reality, the value of Pancasila in the community especially among children began to fade which children act as immoral. One of the causes of the fading values of Pancasila is an education in Indonesia was less imparts the value of Pancasila in the classroom and bores methods of learning, so it makes students less enthusiasm when studies the Citizenship Education. This research produced a board game designed by using the Kumara Studio game method design as innovative media learning. Moreover, this research purpose is also to attract the attention of students to study and implantation the value of a character indirectly through rules in gameplay and directly through guidance given by during playtimes. Responded well given by students and students feel joyful when learning Pancasila using board games. There is also an increase in the grade of students' test results.
\end{abstract}

Keywords: Board Game, Education, Elementary School, Pancasila 


\section{PENDAHULUAN}

Pancasila adalah dasar negara Indonesia yang lahir lewat sidang Badan Penyelidik Usaha Persiapan Kemerdekaan Indonesia (BPUPKI) ketika Indonesia masih berada di bawah penjajahan Jepang. Arti Pancasila secara harafiah adalah lima dasar, dan isi rumusan dari Pancasila yang dikenal secara umum sebagai rumusan negara adalah Ketuhanan Yang Maha Esa, Kemanusiaan yang adil dan beradab, Persatuan Indonesia, Kerakyatan yang dipimpin oleh hikmat kebijaksanaan oleh permusyawaratan perwakilan, dan Keadilan sosial bagi seluruh rakyat Indonesa (Setiawan, 2019). Pancasila memiliki peran sebagai dasar falsafah sekaligus ideologi negara Indonesia yang diharapkan dapat menjadi pandangan hidup bangsa Indonesia sebagai dasar pemersatu, lambang persatuan, dan kesatuan serta pertahanan Bangsa dan Negara Indonesia (Hakim, 2016).

Di Indonesia mulai muncul masalah ekonomi, korupsi, kemiskinan, tawuran antar pelajar, politisi yang hanya mementingkan kepentingan pribadi saja, semua hal ini terjadi karena bangsa ini sudah tidak mengindahkan lagi nilai-nilai yang terkandung di dalam Pancasila (Samudra, 2015). Hal tersebut dinilai sebagai indikasi mulai lunturnya nilai-nilai Pancasila. Bukti lain lunturnya Pancasila juga dapat dilihat dari beberapa kasus kenakalan anak dan remaja bahkan anak sekolah dasar yang berperilaku seperti anak yang tidak memiliki moral. Salah satu kenakalan yang paling sering terjadi yaitu tawuran antar pelajar, contohnya puluhan anak sekolah dasar hendak melakukan tawuran di Semarang. Rasa persatuan di dalam diri anak-anak SD tersebut sudah tidak ada, murid dengan mudahnya melakukan tawuran hanya karena masalah sepele (Nirwana, 2016). Contoh lain juga terjadi baru-baru ini, dimana seorang murid melakukan aksi tidak terpuji dengan merokok saat guru sedang menerangkan pelajaran di depan kelas (Asikin, 2019).

Dewan Pembina Majelis Kebangsaan Pancasila jiwa Nusantara Pusat (Samudra, 2015) mengatakan bahwa salah satu penyebab masalah lunturnya nilai Pancasila adalah kurikulum pendidikan di Indonesia yang sudah kurang menanamkan nilai-nilai Pancasila, mata pelajaran seperti Pendidikan Pancasila dan Kewarganegaraan (PPKn) sudah tidak menjadi pelajaran pokok di sekolah-sekolah. Selain kurangnya materi tentang nilai Pancasila yang ada di dalam pelajaran, dalam penelitian yang dilakukan oleh Setiawan (2014), pembelajaran PPKn yang ada di sekolah dasar kurang menerapkan model pembelajaran yang inovatif, metode pembelajaran yang masih Teacher Centered dan menyebabkan murid tidak aktif saat mengikuti pelajaran. Penelitian yang dilakukan Wijanarko (2014) mendapatkan proses pembelajaran yang digunakan di sekolah masih berupa model yang berfokus pada guru, guru kurang melibatkan siswa dalam diskusi, dan masih rendahnya keaktifan siswa dalam kelas ketika mengikuti pelajaran PPKn. Padahal dengan banyak melibatkan siswa dan membuat mereka aktif dalam mengikuti pelajaran dapat meningkatkan antusiasme dan hasil belajar siswa (Iskandar, 2017). Oleh karena itu penting untuk membuat siswa aktif dalam kegiatan belajar sebagai salah satu upaya untuk menangani masalah lunturnya nilai Pancasila dengan menanamkan nilai Pancasila melalui pelajaran Pendidikan Kewarganegaraan atau Pendidikan Pancasila. 
Perkembangan anak berlangsung sangat cepat dan hal-hal yang anak pelajari pada usia dini akan menjadi penentu bagi karakter anak ketika dewasa. Oleh karena itu sangat penting untuk memanfaatkan masa dini anak untuk mengajarkan nilai karakter yang baik (Prasetyo, 2011). Anak-anak juga dapat mempelajari sesuatu dengan baik jika anakanak dalam kondisi senang, hal ini menjadikan board game sebagai pilihan yang tepat sebagai media pembelajaran (Rosenfeld, 2005). Hasil positif dari penggunaan board game sebagai media pembelajaran dapat dilihat dari penelitian yang telah dilakukan oleh Limantara dkk (2015) yang berjudul "Perancangan Boardgame Untuk Menumbuhkan Nilai-Nilai Moral Pada Remaja". Lewat penelitian ini didapatkan kesimpulan bahwa penyampaian materi dalam bentuk permainan lebih tersampaikan dengan baik, karena siswa tidak merasa bosan jika dibandingkan dengan penyampaian materi lewat pelajaran di kelas yang terkadang membosankan bagi siswa. Begitu juga hasil penelitian yang dilakukan oleh Purwanti (2018) yaitu melalui board game, aspek sosial pada anak juga dapat tersentuh dan mereka dapat belajar tentang sistem nilai dan moral yang berlaku dalam masyarakat. Mekanik permainan co-operative juga dinilai baik, dimana dapat mengajarkan anak-anak untuk saling berbagi, peduli dengan perasaan orang lain dan mengembangkan kemampuan interaksi sosial yang baik, dan manfaat itu berhubungan dengan nilai kemanusiaan dalam Pancasila, sekaligus mendukung proses pendidikan karakter yang membutuhkan lingkungan sosial yang baik (Romano, 2013).

\section{METODE PENELITIAN}

Pada penelitian ini, metode yang digunakan adalah metode perancangan game milik Kummara (Nugroho, 2013), salah satu game developer di Indonesia, dimana board game yang dibuat akan melewati tahapan yang berputar. Tahapan dapat dilihat pada Gambar 1.

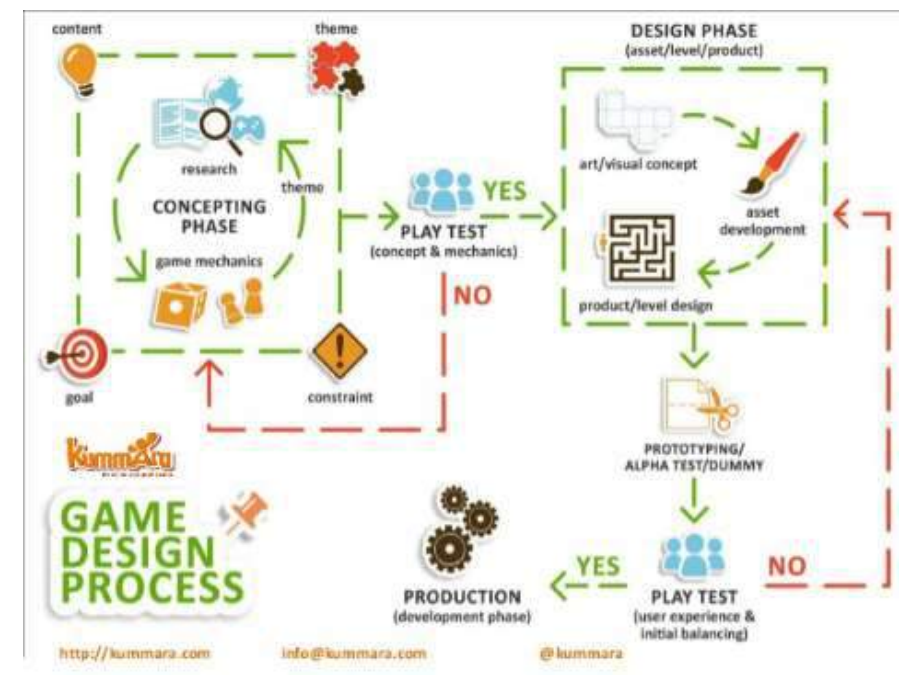

Gambar 1. Tahapan perancangan

[Sumber : slideshare.net/kumara/game-design-process-2013-kummara] 


\subsection{Rancangan Konsep}

Pada tahap ini materi yang akan digunakan dalam permainan dikumpulkan dan dirangkai seperti tema tentang Pancasila. Konten berupa permainan, seperti dadu, kartu, papan permainan dan kebutuhan jenis konten disesuaikan dengan permainan yang akan dibuat. Cara memenangkan permainan serta rancangan peraturan dalam permainan juga dirancang sesuai dengan tema dan tujuan dari permainan.

Pengumpulan data dilakukan secara kualitatif melalui studi pustaka dan wawancara. Wawancara dilakukan bersama dengan wali kelas kelas tiga SD S.t Theresia Marsudirini 77 Salatiga, Ibu Lusia Maryani, S.Pd. SD untuk mendapatkan data tentang materi yang telah diajarkan pada murid dan metode pengajaran yang pernah digunakan di kelas, sekaligus tentang kompetensi dasar yang diharapkan dapat dicapai dari media pembelajaran yang dirancang. Studi pustaka dilakukan dengan mencari data melalui buku, artikel dan jurnal di internet untuk mendapatkan data tentang keadaan Pancasila di Indonesia, nilai yang terkandung di dalam Pancasila, dan pendidikan Pancasila di Indonesia khususnya di SD.

Lewat permainan ini, anak-anak diajak belajar mengenai pengamalan nilai Pancasila di lingkungan sekitar anak melalui kartu dengan cerita yang dimainkan. Anak-anak juga diajak belajar untuk bekerjasama bersama teman-teman dengan penggunaan pion yang digunakan bersama. Berbeda dengan permainan seperti ular tangga, dimana tiap pemain menggunakan 1 pion dan dadu untuk bergerak, permainan ini hanya menggunakan 1 pion untuk 4 pemain dan kartu berwarna untuk bergerak di peta yang memiliki petak-petak warna. Tiap pemain akan menggunakan kartu warna dan pion akan bergerak sesuai dengan kartu yang digunakan. Karena hanya menggunakan 1 pion untuk digunakan bersama, pemain diajak aktif bernegosiasi dengan pemain lainnya untuk menentukan arah jalan pion sesuai dengan kartu berwarna yang pemain miliki. Kecakapan pemain tentang Pancasila dan kerja sama dapat dinilai dari jumlah poin yang bisa pemain kumpulkan dengan menebak sila Pancasila yang sesuai dengan cerita yang ada selama permainan.

Dari permainan ini diharapkan siswa juga dapat menyerap nilai-nilai pembangunan karakter bangsa (Depdiknas, 2003) yang diajarkan secara tidak langsung lewat permainan. Nilai-nilai yang diajarkan adalah nilai taqwa dan jujur, dimana siswa diajak untuk bermain secara jujur dan tidak berbohong mengenai hasil akhir permainan. Nilai berikutnya adalah disiplin, siswa diharapkan dapat patuh terhadap semua aturan yang berlaku di dalam permainan. Demokratis dan adil adalah nilai selanjutnya yang diajarkan kepada siswa, siswa diajarkan untuk mendengarkan pendapat orang lain ketika bernegosiasi dan memperlakukan setiap pemain dalam kelompoknya secara adil tanpa membeda-bedakan. Terakhir nilai tanggung jawab dan gotong royong, siswa dilatih untuk menyelesaikan permainan yang sudah dimulai hingga tuntas secara bersamasama dengan kelompok bermainnya. 


\subsection{Playtest 1}

Setelah konsep awal selesai, dilakukan uji coba untuk dinilai apakah konten dapat tersampaikan dengan baik dengan mekanik permainan yang digunakan, apakah tema dan tujuan permainan cocok dengan mekanik permainan yang dipakai, dan apakah permainan terlalu rumit atau mudah untuk target yang diinginkan. Uji coba dilakukan dengan cara membuat purwarupa sederhana konten-konten permainan yang dirancang. Purwarupa yang dibuat tidak perlu sesempurna hasil akhir, karena tujuannya hanya untuk uji coba gameplay. Setelah purwarupa selesai dibuat, purwarupa di uji coba di komunitas tabletop. Jika sudah sesuai maka dilanjutkan ke tahap desain, jika belum konsep permainan diperbaiki kembali sesuai dengan saran yang diberikan. Purwarupa awal dapat dilihat di Gambar 2.

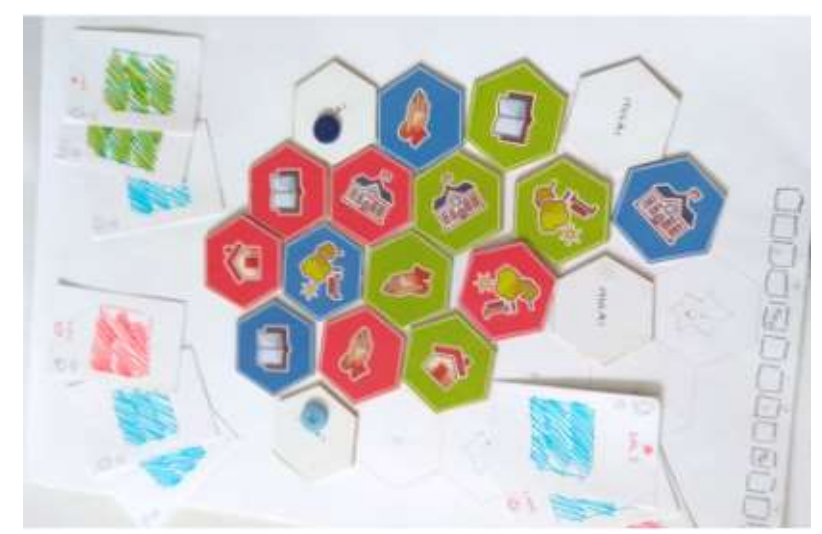

Gambar 2. Purwarupa awal permainan

[Sumber : Dokumentasi Kelvin dkk, 2019]

Pada purwarupa awal, pion dimainkan di atas papan-papan heksagonal yang dapat diacak agar permainan tidak membosankan. Karena papan-papan diatur secara acak, setiap permainan akan memiliki posisi papan yang berbeda dengan permainan sebelumnya. Namun setelah melakukan uji coba, papan-papan permainan diganti dengan peta yang memiliki petak tetap, hal ini dilakukan karena sangat sulit untuk menjaga papan-papan heksagonal tetap rapi terutama jika dimainkan oleh anak-anak. Peta purwarupa yang baru dapat dilihat di Gambar 3.

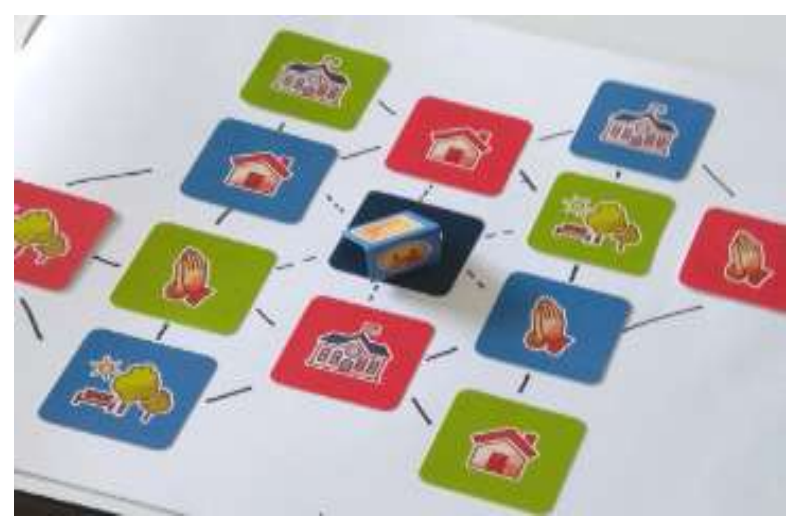

Gambar 3. Peta purwarupa baru dengan petak tetap [Sumber : Dokumentasi Kelvin dkk, 2019] 


\subsection{Pembuatan Asset}

Pada tahap ini asset yang akan dipakai dalam board game dibuat, asset dapat berupa bentuk kartu atau papan, dan ilustrasi yang akan dipakai di dalam permainan. Pembuatan asset menggunakan software grafis yang ada di komputer. Gambar dan warna yang digunakan menggunakan style gambar kartun dan warna yang cerah untuk menarik perhatian murid-murid dengan memperhatikan ukuran teks dan warna teks yang sesuai agar dapat terbaca dengan baik.

\subsection{Prototyping}

Setelah desain selesai, purwarupa dari permainan dicetak. Kertas yang dipakai menggunakan Art Paper karena kertas tebal dan tidak mudah rusak, pion-pion dibuat dengan menggunakan Art Paper dan Yellow Board untuk memberikan ketebalan tambahan seperti koin. Setelah semua komponen dicetak, dilakukan tes kembali di tahapan selanjutnya.

\subsection{Playtest 2}

Pada tahap ini, purwarupa permainan dinilai untuk melihat kenyamanan pemain ketika bermain. Hal yang dinilai seperti, apakah tulisan dapat dibaca dengan baik, apakah warna yang digunakan tidak melelahkan mata pemain, apakah ukuran kartu atau benda lain di dalam permainan seperti token nyaman saat permainan berlangsung. Jika sudah sesuai, dapat dilanjutkan ke tahap selanjutnya. Jika belum desain diperbaiki kembali. Pada ujicoba yang kedua, materi Pancasila berupa soal yang dicetak pada kartu dengan jawaban di belakangnya. Contoh kartu dapat dilihat di Gambar 4.

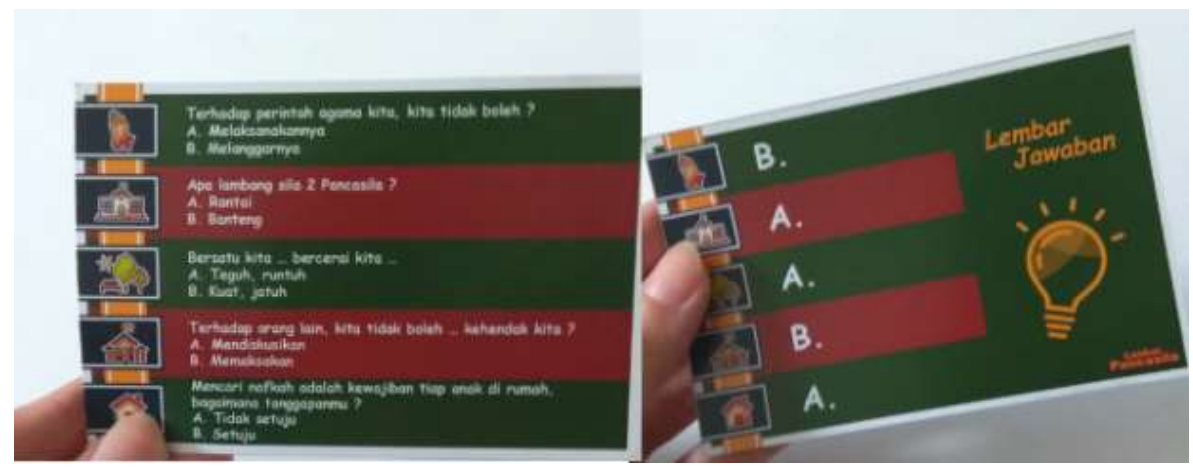

Gambar 4. Contoh kartu soal dan jawaban di belakangnya

[Sumber : Dokumentasi Kelvin dkk, 2019]

Menurut guru wali kelas 3 SD St. Theresia Marsudirini 77 Salatiga, murid-murid masih perlu melihat contoh nyata untuk dapat memahami sesuatu. Meletakan jawaban di belakang kartu juga dinilai tidak efektif karena anak-anak dapat bermain dengan curang. Dari pertimbangan tersebut kartu soal diganti menjadi Kartu Masalah dengan cerita dan nilai Pancasila yang berkaitan dengan masalah. Masalah diletakkan di dalam kartu bukan di balik kartu. Kartu di desain seperti buku dengan kunci kait, sehingga tidak mudah untuk dilihat jika kait tidak dibuka. Desain Kartu Masalah baru dapat dilihat di Gambar 5 . 

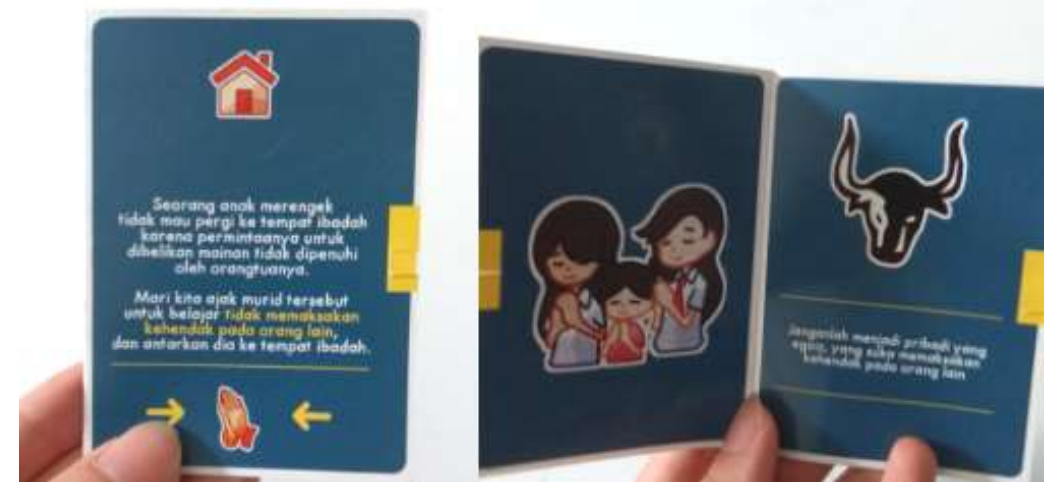

Gambar 5. Kartu masalah baru dengan kait berwarna kuning

[Sumber : Dokumentasi Kelvin dkk, 2019]

\subsection{Produksi}

Setelah semua tahap terlewati, game siap untuk diproduksi. Game yang telah di cetak dapat dilihat pada Gambar 6.

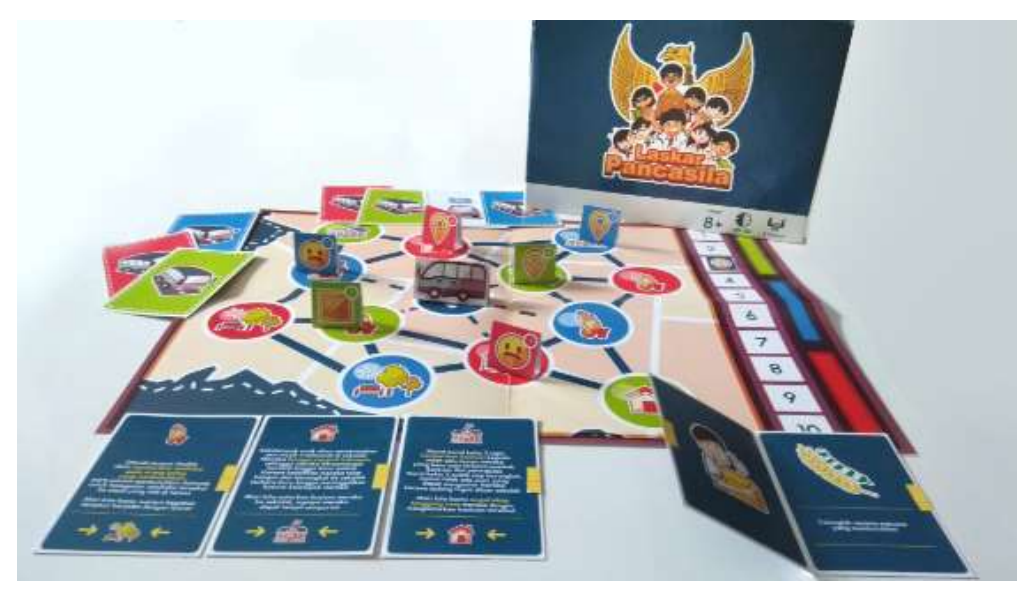

Gambar 6. Game yang sudah dicetak dengan komponen-komponennya [Sumber : Dokumentasi Kelvin dkk, 2019]

\subsection{Pengujian}

Dilakukan dua kali pengujian, yaitu pengujian buku panduan dan pengujian permainan. Pengujian buku panduan dilakukan kepada empat murid SD kelas 3 yang sama sekali belum pernah melihat dan memainkan permainan. Pada saat pengujian, murid-murid tidak diberitahu bagaimana cara memainkan permainan, murid-murid diminta untuk mempelajari sendiri cara memainkan permainan lewat buku panduan yang tersedia, lalu dinilai apakah murid-murid dapat bermain dengan benar.

Hasil pengujian buku panduan yang didapat diketahui bahwa total waktu yang dibutuhkan untuk membaca buku panduan 8 menit 36 detik, untuk melakukan set-up permainan 9 menit 40 detik, dan untuk bermain hingga selesai 26 menit 39 detik, sehingga total waktu untuk bermain sekitar 44 menit 55 detik. Adanya ketertarikan dengan permainan dilihat dari antusias murid-murid melihat kotak permainan dan membaca keterangan yang berada di bagian belakang kotak. Namun saat membaca buku panduan, tidak ada diskusi yang terjadi karena hanya 1 murid yang membaca, 
selebihnya murid-murid malas membaca buku panduan tersebut. Saat melakukan setup permainan, para murid dibantu dengan gambar yang ada di dalam buku panduan sehingga dapat melakukan set-up dengan benar. Permainan juga berjalan dengan benar, namun pada bagian akhir permainan, para murid mulai bermain dengan curang, seperti membuka Kartu Masalah untuk melihat jawaban sila Pancasila, dan bermain tidak sesuai dengan urutan pemain untuk memudahkan ketika menjalankan pion pemain yang digunakan secara bersama-sama.

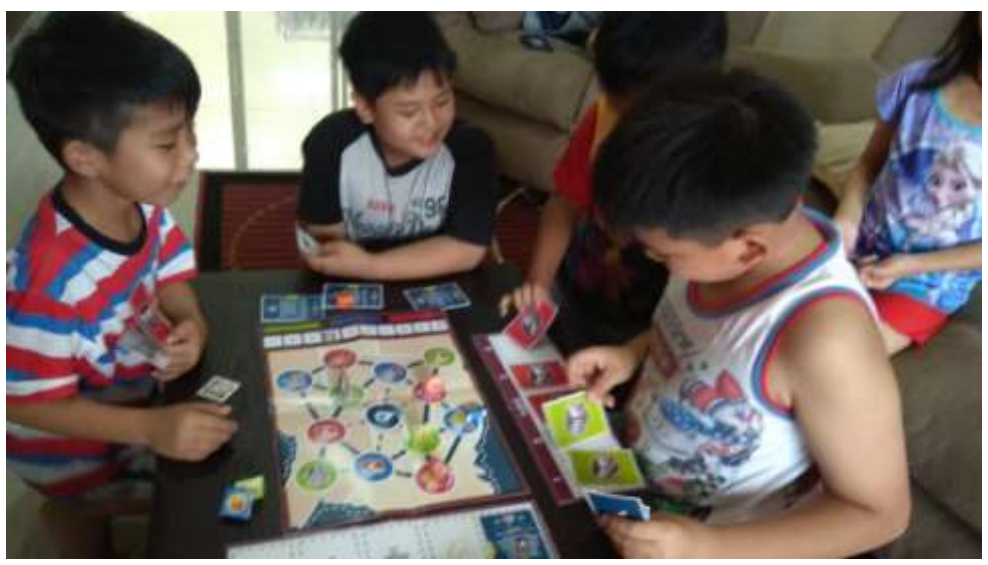

Gambar 7. Pengujian buku panduan [Sumber : Dokumentasi Kelvin dkk, 2019]

Kesimpulan dari pengujian buku panduan adalah buku panduan sudah baik dan dapat membantu berjalannya permainan. Ada beberapa kata yang menurut murid-murid sulit dipahami yaitu fase dan pion, diganti menjadi kata tahap untuk fase dan bidak untuk pion.

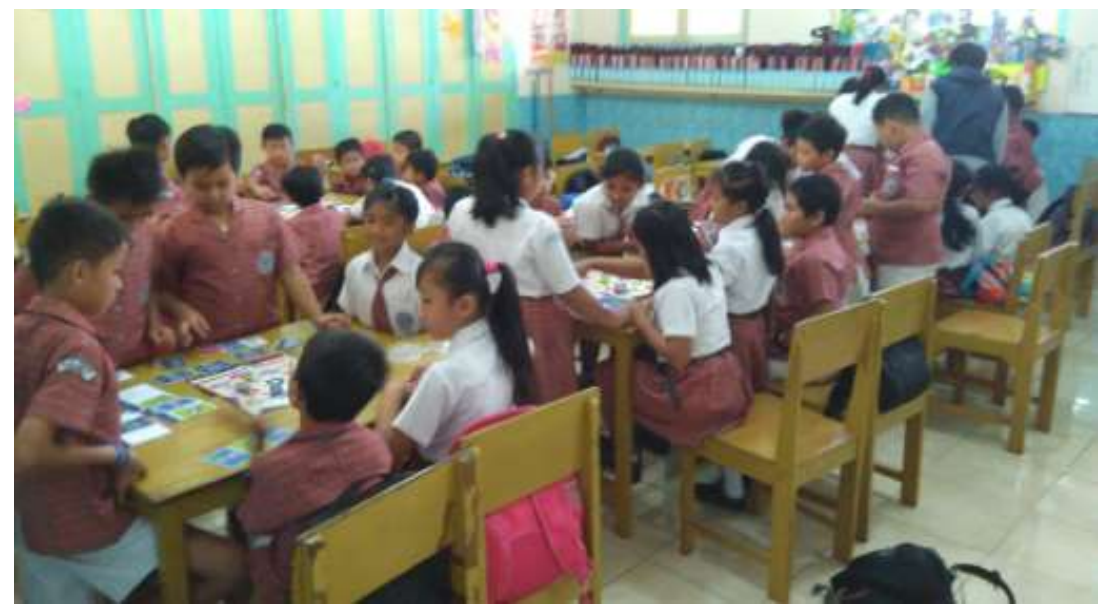

Gambar 8. Sesi bermain di dalam kelas kelas 3

[Sumber : Dokumentasi Kelvin dkk, 2019]

Pengujian permainan dilakukan bersama dengan 35 murid di kelas 3 SD St. Theresia Marsudirini 77 Salatiga. Pada hari Senin 12 Juni 2017, murid-murid diberi tes dan kuesioner untuk mendapatkan nilai tiap anak tentang pengetahuan Pancasila. Lalu murid-murid diajak bermain pada hari Kamis tanggal 15 Juni 2017. Ketika bermain, murid-murid diberitahu cara dan aturan bermain, setelah itu murid-murid dibiarkan 
bermain sendiri hingga permainan selesai, bantuan diberikan jika murid-murid kesulitan saat bermain. Setelah selesai bermain, murid-murid kembali diberi tes dan kuesioner yang sama untuk menilai perkembangan murid-murid dan pendapat murid-murid tentang permainan yang baru saja murid-murid mainkan. Gambar 8 di atas adalah gambar ketika murid-murid sedang bermain.

\subsection{Penulisan Laporan}

Penulisan laporan dimulai dari awal penelitian hingga hasil pengujian untuk melihat apakah tujuan dan manfaat penelitian ini tercapai dan hasilnya berguna untuk subjek penelitian.

\section{HASIL DAN PEMBAHASAN}

Setelah data dari tes dan kuesioner telah diisi secara lengkap dan baik oleh 35 murid kelas 3 SD St. Theresia Marsudirini 77 Salatiga dengan 21 murid laki-laki, 14 perempuan, nilai tiap murid dihitung dan dikelompokkan ke dalam dua jenis nilai yaitu nilai tes dan pendapat para murid tentang game Laskar Pancasila yang murid mainkan.

Nilai tes, untuk menghitung nilai tes tiap murid digunakan rumus menghitung nilai ratarata (Purwanto, 2009).

$$
\text { Nilai }=\frac{\text { Jawaban benar }}{\text { Total soal }} \times 100
$$

Kriteria penilaian yang digunakan dapat dilihat di Tabel 1 (Kemendikbud, 2013).

Tabel 1. Kriteria nilai tes

[Sumber : Dokumentasi Kelvin dkk, 2019]

\begin{tabular}{|c|c|}
\hline Nilai & Predikat \\
\hline $91.75<\mathrm{N} \leq 100$ & A \\
\hline $83.25<\mathrm{N} \leq 91.75$ & A- \\
\hline $75.00<\mathrm{N} \leq 83.25$ & $\mathrm{~B}+$ \\
\hline $66.75<\mathrm{N} \leq 75.00$ & $\mathrm{~B}$ \\
\hline $58.25<\mathrm{N} \leq 66.75$ & $\mathrm{~B}-$ \\
\hline $50.00<\mathrm{N} \leq 58.25$ & $\mathrm{C}+$ \\
\hline $41.75<\mathrm{N} \leq 50.00$ & $\mathrm{C}$ \\
\hline $33.25<\mathrm{N} \leq 41.75$ & $\mathrm{C}-$ \\
\hline $25.00<\mathrm{N} \leq 33.25$ & $\mathrm{D}+$ \\
\hline $00.00<\mathrm{N} \leq 25.00$ & $\mathrm{D}$ \\
\hline
\end{tabular}

Hasil analisis dari perhitungan nilai dari tes yang dikerjakan oleh murid-murid sebelum dan setelah bermain dapat dilihat di Tabel 2 . 
Tabel 2. Hasil Tes murid-murid sebelum dan setelah bermain [Sumber : Dokumentasi Kelvin dkk, 2019]

\begin{tabular}{|c|c|c|c|c|c|}
\hline \multirow{2}{*}{ No. } & \multicolumn{2}{|c|}{ Nilai } & \multicolumn{2}{|c|}{ Predikat } & \multirow{2}{*}{ Keterangan } \\
\hline & Sebelum & Sesudah & Sebelum & Sesudah & \\
\hline 1 & 77.7 & 77.7 & $\mathrm{~B}+$ & $\mathrm{B}+$ & Tetap \\
\hline 2 & 77.7 & 88.8 & $\mathrm{~B}+$ & A- & Naik \\
\hline 3 & 72.2 & 83.3 & B & A- & Naik \\
\hline 4 & 77.7 & 94.4 & $B+$ & A & Naik \\
\hline 5 & 77.7 & 88.8 & $\mathrm{~B}+$ & A- & Naik \\
\hline 6 & 83.3 & 83.3 & A- & A- & Tetap \\
\hline 7 & 61.1 & 83.3 & B- & A- & Naik \\
\hline 8 & 61.1 & 77.7 & B- & $B+$ & Naik \\
\hline 9 & 61.1 & 83.3 & B- & A- & Naik \\
\hline 10 & 66.6 & 77.7 & B- & $B+$ & Naik \\
\hline 11 & 61.1 & 72.2 & B- & $B$ & Naik \\
\hline 12 & 61.1 & 72.2 & B- & $\mathrm{B}$ & Naik \\
\hline 13 & 61.1 & 94.4 & B- & A & Naik \\
\hline 14 & 61.1 & 88.8 & B- & A- & Naik \\
\hline 15 & 61.1 & 88.8 & B- & A- & Naik \\
\hline 16 & 61.1 & 55.5 & B- & $\mathrm{C}+$ & Turun \\
\hline 17 & 66.6 & 94.4 & B- & A & Naik \\
\hline 18 & 66.6 & 83.3 & B- & A- & Naik \\
\hline 19 & 72.2 & 72.2 & $B$ & B & Tetap \\
\hline 20 & 72.2 & 88.8 & $B$ & A- & Naik \\
\hline 21 & 66.6 & 61.1 & B- & B- & Turun \\
\hline 22 & 61.1 & 44.4 & B- & $\mathrm{C}$ & Turun \\
\hline 23 & 55.5 & 66.6 & $\mathrm{C}+$ & B- & Naik \\
\hline 24 & 55.5 & 66.6 & $\mathrm{C}+$ & B- & Naik \\
\hline 25 & 55.5 & 50 & $\mathrm{C}+$ & $\mathrm{C}+$ & Turun \\
\hline 26 & 50 & 77.7 & $\mathrm{C}+$ & $\mathrm{B}+$ & Naik \\
\hline 27 & 50 & 72.2 & $\mathrm{C}+$ & $\mathrm{B}$ & Naik \\
\hline 28 & 55.5 & 44.4 & $\mathrm{C}+$ & $C$ & Turun \\
\hline 29 & 55.5 & 77.7 & $\mathrm{C}+$ & $\mathrm{B}+$ & Naik \\
\hline 30 & 50 & 88.8 & $\mathrm{C}+$ & A- & Naik \\
\hline 31 & 44.4 & 72.2 & $C$ & $B$ & Naik \\
\hline 32 & 38.8 & 55.5 & C- & $\mathrm{C}+$ & Naik \\
\hline 33 & 38.8 & 44.4 & C- & $C$ & Naik \\
\hline 34 & 66.6 & 77.7 & B- & $\mathrm{B}+$ & Naik \\
\hline 35 & 61.1 & 83.3 & B- & A- & Naik \\
\hline
\end{tabular}

Pada tabel 2 dapat dilihat adanya kenaikan hasil tes dari murid-murid setelah bermain sebesar $21.53 \%$, dari nilai rata-rata kelas sebesar 61.8 menjadi 75.1 . Jumlah murid yang mendapatkan peningkatan nilai sebanyak 27 murid, sedangkan yang nilainya tetap ada 3 murid, dan sebanyak 5 murid mengalami penurunan nilai setelah bermain. Melihat tabel ini, dapat disimpulkan bahwa board game dapat membantu para murid untuk meningkatkan kemampuan belajar murid, walaupun ada beberapa individu yang tidak 
atau bahkan mengalami penurunan. Menurut guru wali murid-murid, ibu Lusia Maryani, hal ini disebabkan karena kemampuan tiap anak yang berbeda dalam mempelajari sesuatu, ada yang senang belajar dengan gambar, dengan membaca, atau bermain, sehingga menyebabkan kemungkinan suatu media pembelajaran memberikan hasil yang berbeda pada tiap murid.

Selain perkembangan nilai, guru juga dapat memantau nilai karakter murid selama permainan berlangsung, apakah kelompok murid mau bermain bersama dengan temanteman secara baik ataupun tidak. Guru dan pembimbing dapat menggunakan daftar nilai-nilai pembangun karakter bangsa milik Depdiknas untuk melihat apakah murid sudah memiliki karakter yang baik atau belum. Proses pembimbingan selama bermain juga efektif karena murid juga dapat melihat dan merasakan secara langsung contoh pengamalan nilai karakter yang baik.

Pada kegiatan bermain ini, dapat dilihat sebagian besar murid sudah dapat bermain bersama dengan baik, para murid saling mendengarkan pendapat anggota kelompok, bahkan ada yang berusaha memimpin dengan baik ketika diskusi saat diskusi mulai tidak terarah. Ada juga kelompok bermain yang malah didominasi oleh 1 murid dan murid lainnya tidak dapat mengutarakan pendapat. Pada saat inilah peran guru dan pembimbing dibutuhkan untuk memperbaiki karakter dominasi pada murid tersebut, dan mencoba untuk membimbing murid tersebut supaya mau bersikap demokratis, begitu juga dengan anggota lainnya agar berani menyampaikan pendapat.

Untuk mendapatkan hasil dari kuesioner pendapat murid tentang Game Laskar Pancasila, digunakan kuesioner skala Likert 5 poin dengan pernyataan positif (Riduwan, 2015). Untuk penilaian skor tiap pernyataan dalam kuesioner digunakan rumus :

$$
\text { Nilai Pernyataan }=\frac{\text { Jumlah nilai dari responden }}{\text { Nilai likert tertinggi } x \text { responden }} \times 100 \%
$$

Jarak interval kriteria penilaian yang digunakan memiliki 5 skala nilai, jarak interval untuk kriteria penilaian adalah $20 \%$, dengan urutan seperti pada Tabel 3.

Tabel 3. Kriteria pendapat murid

[Sumber : Dokumentasi Kelvin dkk, 2019]

\begin{tabular}{|l|l|}
\hline \multicolumn{1}{|c|}{ Indeks Persentase } & \multicolumn{1}{c|}{ Kriteria } \\
\hline $81 \%-100 \%$ & Sangat baik \\
\hline $61 \%-80 \%$ & Baik \\
\hline $41 \%-60 \%$ & Cukup \\
\hline $21 \%-40 \%$ & Kurang \\
\hline $0 \%-20 \%$ & Sangat kurang \\
\hline
\end{tabular}


Untuk hasil analisis dari pendapat murid tentang Game Laskar Pancasila dapat dilihat pada Tabel 4, dengan keterangan pernyataan, STS : Sangat Tidak Setuju; TS : Tidak Setuju; N : Netral; S : Setuju; SS : Sangat Setuju.

Tabel 4. Hasil kuesioner pendapat murid tentang Game Laskar Pancasila

[Sumber : Dokumentasi Kelvin dkk, 2019]

\begin{tabular}{|c|l|c|c|c|c|c|c|}
\hline No & \multicolumn{1}{|c|}{ Pernyataan } & STS & TS & N & S & SS & Nilai \\
\hline 1 & Game Laskar Pancasila menarik & 0 & 0 & 0 & 8 & 27 & $95.4 \%$ \\
\hline 2 & Game mudah dimainkan & 1 & 4 & 2 & 10 & 18 & $82.8 \%$ \\
\hline 3 & Materi di dalam game berguna & 0 & 1 & 1 & 6 & 27 & $93.7 \%$ \\
\hline 4 & $\begin{array}{l}\text { Saya mendapat pengetahuan baru tentang } \\
\text { Pancasila setelah bermain }\end{array}$ & 0 & 0 & 0 & 9 & 26 & $94.8 \%$ \\
\hline 5 & Mudah bermain secara co-operative & 0 & 0 & 2 & 16 & 17 & $88.5 \%$ \\
\hline 6 & $\begin{array}{l}\text { Saya dapat berdiskusi dengan baik selama } \\
\text { bermain }\end{array}$ & 1 & 1 & 3 & 6 & 24 & $89.1 \%$ \\
\hline 7 & Gambar dalam game menarik & 0 & 0 & 2 & 9 & 24 & $92.5 \%$ \\
\hline 8 & Warna dalam game nyaman dilihat & 0 & 0 & 3 & 9 & 23 & $91.4 \%$ \\
\hline 9 & Tulisan dalam game dapat dibaca dengan jelas & 1 & 0 & 1 & 11 & 22 & $90.2 \%$ \\
\hline 10 & Buku peraturan mambantu permainan & 0 & 1 & 1 & 15 & 18 & $88.5 \%$ \\
\hline 11 & Saya tertarik untuk bermain lagi & 0 & 1 & 1 & 5 & 28 & $94.2 \%$ \\
\hline
\end{tabular}

Dari Tabel 4, dapat dilihat bahwa dari 32 murid berpendapat bahwa game Laskar Pancasila sangat baik, 3 murid yang berpendapat baik, dan ada 1 murid yang menyatakan tidak tertarik untuk memainkan game ini lagi. Hal tersebut mungkin disebabkan karena game masih dinilai sulit untuk murid-murid, dilihat dari 1 murid yang berpendapat game sangat sulit dimainkan, dan 4 murid yang berpendapat game sulit dimainkan. Namun secara keseluruhan, murid-murid berpendapat boardgame ini memiliki nilai sangat baik.

\section{KESIMPULAN}

Pancasila sebagai ideologi dan dasar negara Indonesia memiliki peranan yang sangat penting sebagai pedoman dalam kehidupan bernegara, namun nilainya yang mulai luntur di masyarakat terutama di kalangan anak muda, menyebabkan munculnya banyak masalah moral seperti, tawuran antar pelajar, dan tidak menghormati guru. Pendidikan Pancasila yang dinilai kurang inovatif menjadi salah satu penyebab murid kurang bersemangat mengikuti pelajaran kewarganegaraan di sekolah. Hal tersebut menyebabkan prestasi yang tidak maksimal dan nilai moral Pancasila yang tidak tersampaikan dengan baik kepada murid. Salah satu cara untuk mengatasi masalah ini adalah dengan membuat media pembelajaran yang menyenangkan bagi murid.

Melalui boardgame, materi Pancasila dapat diajarkan kepada murid dengan cara yang menyenangkan, murid juga dapat diajarkan tentang toleransi dan kebersamaan lewat permainan co-operative. Hasilnya dapat dilihat dari perkembangan nilai setelah belajar 
menggunakan boardgame. Selama permainan guru juga mempunyai kesempatan untuk menilai, menguatkan dan memperbaiki nilai-nilai karakter setiap anak dengan tujuan untuk mengembangkan karakter Pancasila pada diri mereka. Boardgame juga diterima dengan baik oleh murid-murid melihat kuesioner pendapat murid tentang boardgame. Walau sudah dinilai positif oleh murid-murid, pengembangan masih dapat dilakukan dengan tujuan untuk mempermudah permainan karena masih ada beberapa murid yang kesulitan dan menambah materi Pancasila di dalamnya.

\section{DAFTAR PUSTAKA}

Asikin, M. N. 2019. Viral! Guru Sibuk Mengajar, Pelajar Asyik Merokok, Retrieved from Jawapos: https://www.jawapos.com/jpg-today/24/01/2019/viral-guru-sibukmengajar-pelajar-asyik-merokok/

Depdiknas. 2003. Mata Pelajaran Kewarganegaraan, Jakarta : Depdiknas Dirjen Pendidikan Dasar dan Mengengah Direktorat Pendidikan Mengengah Umum.

Hakim, A. M. 2016. Pengertian, Fungsi, dan Tujuan Pancasila, Retrieved from Yuksinau: http://www.yuksinau.com/2016/02/pengertian-fungsi-dan-tujuanpancasila.html

Iskandar, Rossi. 2017. Meningkatkan Hasil Belajar Pendidikan Pancasila dan Kewarganegaraan Melalui Metode Role Playing di Kelas IV Sekolah Dasar, Jurnal IImiah Pendidikan Guru Sekolah Dasar, 1 (2), 8, 2017, pp.135-144.

Kemendikbud. 2013. Panduan Teknis Penilaian Di Sekolah Dasar, Jakarta: Kementrian Pendidikan dan Kebudayaan Direktorat Jenderal Pendidikan Dasar Direktorat Pembinaan Sekolah Dasar.

Limantara, D. 2015. Perancangan Board Game Untuk Menumbuhkan Nilai-Nilai Moral Pada Remaja, Jurnal DKV Adiwarna, 1 (6), 2015.

Nirwana, R. 2016. Lunturnya Pancasila Siswa SD di Semarang Ajak Tawuran Pakai Benda Tajam, Retrieved from Kompasiana: http://www.kompasiana.com/rachellenirwana/lunturnya-pancasila-siswa-sddi-semarang-ajak-tawuran-pakai-benda-tajam_583862165eafbd7108e87fa1

Nugroho, E. 2013. Game Design Process, Retrieved from SlideShare: https://www.slideshare.net/kummara/game-design-process-2013-kummara

Prasetyo, Nana. 2011. Membangun Karakter Anak Usia Dini, Jakarta: Direktorat Pembinaan Pendidikan Anak Usia Dini.

Purwanti, Retno. 2018. Build Sosical Interaction and Local Value in Children through Board Game Interface Design, IDEALOGY, 3 (3), 12, 2018, pp.102-113.

Purwanto, M. N. 2009. Prinsip-prinsip \& Teknik Evaluasi Pengajaran, Bandung: Remaja Rosdakarya.

Riduwan. 2015. Skala Pengukuran Variabel-Variabel Penelitian, Bandung: ALFABETA.

Romano, L. 2013. Awesome Cooperative Classroom Games, Retrieved from Teachhub: http://www.teachhub.com/6-awesome-cooperative-classroom-games

Rosenfeld, A. 2005. The Benefits of Board Games, Retrieved from scholastic: http://www.scholastic.com/parents/resources/article/creativityplay/benefits-board-games. 
Rosenfeld, N. 2015. Nilai-Nilai Pancasila Sudah Mulai Luntur, Retrieved from patriot garuda: http://patriotgaruda.com/2015/09/01/nilai-nilai-pancasila-sudahmulai-luntur/

Setiawan, D. 2014. Pendidikan Kewarganegaraan Berbasis Karakter melalui Penerapan Pendekatan Pembelajaran Aktif, Kreatif, Efektif, dan Menyenangkan. Jurnal Pendidikan Ilmu-ilmu Sosial, 6 (2), 1, 2015, pp.61-72.

Setiawan, P. 2019. Sejarah Perumusan Pancasila Berdasarkan UUD 1945 Terlengkap, Retrieved from Guru Pendidikan: https://www.gurupendidikan.co.id/sejarahpancasila/

Wijanarko, P. D. 2014. Numbered Head Together Berbantuan Media Visual Untuk Meningkatkan Kualitas Pembelajaran PKn, Joyful Learning Journal, 4 (3), 9, 2015, pp.24-30. 